\title{
Management of Non-obstetric Acute Abdomen During Pregnancy: A High Volume Maternity Center Experience
}

\section{Gebelikte Doğumsal Olmayan Akut Karın Yönetimi: Yüksek Volümlü Doğum Merkezi Deneyimi}

Yasin Kara, (D) Erkan Somuncu

University of Health Sciences Turkey, Kanuni Sultan Süleyman Training and Research Hospital, Clinic of General Surgery, İstanbul, Turkey

\begin{abstract}
Introduction: The objectives of this study are to analyse and present the cases of pregnant patients who were operated due to non-obstetrical causes, and discuss the ideal diagnostic and therapeutic approaches in the light of current literature.

Methods: We retrospectively reviewed the medical records of pregnant patients who underwent surgery because of non-obstetric pathologies at our clinic between January 2013 and December 2019. Additionally, we evaluated the data of patients such as their demographics, gestational age, clinical and operative findings, diagnostic and therapeutic modalities, hospital stay time, maternal/foetal mortality, and morbidities.

Results: The study cohort consisted of 52 patients who underwent non-obstetrical surgery. The patients' mean age was $26.8 \pm 7.1$ years. In total, $44 \%$ of all cases were in the second trimester. There were following indications for surgery among patients: acute appendicitis (AA) in $67 \%$, acute biliary pancreatitis in $17 \%$, acute cholecystitis in $4 \%$, ovarian cyst rupture in $4 \%$ and other indications in $8 \%$ of patients. Laparoscopy was used in 35\% of the operations, whereas $2 \%$ of the patients required postoperative intensive care unit support. Preterm delivery occurred in 6\%, and miscarriage occurred in $2 \%$ of all cases. Foetal/maternal mortality was $2 \%$ in all cases. Moreover, $49 \%$ of AA cases were observed in the second trimester. Negative appendectomy rate was $9 \%$. The number of perforated cases was six (17\%). Five cases with perforated AA developed wound infection and were treated conservatively.
\end{abstract}

Conclusion: Understanding anatomical and physiological changes in pregnancy, gaining sufficient information about the safe limits of radiological imaging, and a multidisciplinary systematic approach are indispensable for the timely diagnosis and treatment of pregnant women presenting with acute abdomen. Open or laparoscopic surgery for non-obstetric indications during pregnancy can be performed safely, without increases in maternal and foetal mortality, miscarriage, and preterm delivery rates.

Keywords: Non-obstetric surgery, acute abdomen, pregnancy, acute pancreatitis, acute appendicitis

\section{ÖZ}

Amaç: Çalıșmamızın amaçları obstetrik olmayan nedenlerle ameliyat edilen gebe hastaları analiz etmek ve sunmak mevcut literatür ışığında ideal tanı ve tedavi yaklașımlarını tartışmaktır.

Yöntemler: Ocak 2013 - Aralık 2019 tarihleri arasında kliniğimizde obstetrik olmayan patolojiler nedeniyle ameliyat edilen 52 gebenin tıbbi kayıtları retrospektif olarak incelendi. Hastaların demografik özellikleri, gebelik yaşı, klinik ve operatif bulgular, tanı ve tedavi yöntemleri, hastanede kalış süresi, anne/fetal mortalite veya morbidite verileri değerlendirildi.

Bulgular: Çalışma grubu obstetrik nedenli olmayan cerrahi uygulanan 52 hastadan oluşmakta idi. Hastaların ortalama

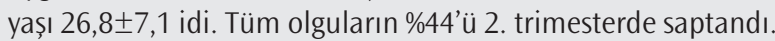
Ameliyat endikasyonları olguların \%67'sinde akut apandisit, \%17'sinde akut biliyer pankreatit, \%4'ünde akut kolesistit, \%4'ünde over kist rüptürü ve \%8'inde diğer endikasyonlardı. Tüm ameliyatların \%35’i laparoskopik yapıldı. Ameliyat sonrası yoğun bakım ünitesi desteği $\% 2$ olguda gerekli oldu. Tüm olguların \%6'sında erken doğum, \%2'sinde düşük meydana geldi. Fetal /maternal mortalite oranı tüm olgularda $\% 2$ idi. Akut apandisit olgularının \%49'u 2. trimesterde saptandı. Negatif apendektomi oranı \%9 idi. Altı olgu (\%17) perfore idi. Perfore akut apandisitli beș olguda yara yeri enfeksiyonu geliști ve konservatif olarak tedavi edildi.

Sonuç: Gebelikteki anatomik ve fizyolojik değișiklikleri anlamak, radyolojik görüntülemenin güvenli sınırları hakkında yeterli bilgiye sahip olmak ve multidisipliner sistematik bir yaklașım, akut karın ile başvuran gebelerin zamanında tanı ve tedavisi için vazgeçilmezdir. Gereklilik halinde, gebelikte obstetrik olmayan endikasyonlar için, açık veya laparoskopik cerrahi, maternal ve fetal mortalite, düșük ve erken doğum oranlarında artış olmadan güvenli bir șekilde yapılabilir.

Anahtar Kelimeler: Obstetrik olmayan cerrahi, akut batın, gebelik, akut pankreatit, akut apandisit
Address for Correspondence/Yazıșma Adresi: Yasin Kara MD, University of Health Sciences Turkey, Kanuni Sultan Süleyman Training and Research Hospital, Clinic of General Surgery, İstanbul, Turkey Phone: +90 5056410226 E-mail: yasinkara32@windowslive.com ORCID ID: orcid.org/0000-0002-9723-1774

Cite this article as/Atıf: Kara Y, Somuncu E. Management of Non-obstetric Acute Abdomen During Pregnancy: A High Volume Maternity Center Experience. İstanbul Med J 2020; 21(3): 170-6.
Received/Geliș Tarihi: 10.03 .2020 Accepted/Kabul Tarihi: 08.04.2020

(C) Copyright 2020 by the University of Health Sciences Turkey, Istanbul Training and Research Hospital/istanbul Medical Journal published by Galenos Publishing House.

(C) Telif Hakkı 2020 Sağılk Bilimleri Üniversitesi Istanbul Eğitim ve Araştırma Hastanesi/Istanbul Tıp Dergisi, Galenos Yayınevi tarafından basılmıștır. 


\section{Introduction}

The differential diagnosis of acute abdomen during pregnancy is extensive because this condition may be caused by any of the gynaecologic or obstetric diseases related to gestation, and by any intraabdominal diseases unrelated to pregnancy (1). The non-obstetric causes of acute abdomen in pregnant women remain the most challenging diagnostic and therapeutic dilemmas for both gynaecologists and general surgeons (1). Diagnosis and management of these diseases and the precise decision of surgery may still be difficult despite recent advancements in imaging and medical technologies (2). Difficulties in the diagnosis and management of acute abdomen in pregnant patients can result from several factors: (a) Dislocation of intraa-bdominal organs caused by an enlarged uterus. (b) Commonly encountered complaints such as nausea, vomiting, and abdominal pain among pregnant women (c) General avoidance of unnecessary surgery in pregnant women (2).

As a high-volume referral centre with the highest number of child births and obstetric surgeries in our country, the objectives of our study are to (a) analyse and present the cases of pregnant women with nonobstetrical causes of acute abdomen; (b) discuss the ideal diagnostic and therapeutic approaches in the light of literature; and (c) raise the awareness of non-obstetrical causes during pregnancy for gynaecologists, general surgeons and emergency medicine specialists.

\section{Methods}

We enrolled pregnant patients with non-obstetrical causes of acute abdomen requiring surgical intervention. These patients were admitted in the surgical wards from January 2013 to December 2019. We retrospectively obtained the data of pregnant women who underwent non-obstetrical surgery from the electronic hospital records and patient files, which were included in the hospital archives, polyclinic visits and phone calls.

We excluded pregnant women with obstetrical reasons for the acute abdomen (ectopic pregnancy, uterine rupture, etc.), women who were followed-up or treated conservatively and women with incomplete data from the study.

Importantly, we recorded the demographic features (age, gender), symptoms and signs at admission, imaging results, gestational age, operation time (using intra-operative anaesthesia and follow-up forms), operative results, histopathological results, laboratory findings, postoperative complications, and delivery outcomes.

The study was approved by the ethics committee of University of Health Sciences Turkey, Kanuni Sultan Süleyman Training and Research Hospital (KAEK/2020.05.28). This study was conducted according to the principles of the Helsinki Declaration. We routinely informed all the patients who provided their written consent.

All pregnant women were examined by a gynaecologist and general surgeon before surgery. Uterine contractions, foetal heart rate and movements were also routinely followed. Physical examination, ultrasonography and laboratory were employed for the diagnosis of acute appendicitis (AA). Alvarado score was calculated in every patient with suspected AA. Ultrasonography was also used for confirming pregnancy. The diagnosis of acute biliary pancreatitis (ABP) was based on the clinical examination, laboratory findings, hyperamylasemia or hyperlipasemia, and ultrasonography. Ranson score of each patient was also calculated to determine the severity of the disease. For the diagnosis of acute cholecystitis (AC), local and systemic signs of inflammation such as Murphy sign, fever, C-reactive protein, elevated leukocyte count and ultrasonography findings were used. The other causes of abdominal pain were diagnosed via physical examination, laboratory results, imaging and intra-operative findings.

\section{Statistical Analysis}

We used SPSS Windows version 15.0 statistics program (SPSS, Inc. Chicago, IL) to evaluate the data. Continuous variables were expressed as mean \pm standard deviation, whereas categorical variables were expressed as percentage values and the number of patients.

\section{Results}

Among a total of 46.756 births from January 2013 to December 2019, 109 pregnant patients were recorded to be hospitalised in the surgery wards for having acute abdominal pain due to non-obstetrical causes. Of these, $\mathrm{ABP}$ and $\mathrm{AC}$ were detected in 57 patients with the diagnosis of nonspecific pain. These patients needed conservative management. Of these patients, we included 52 pregnant patients who underwent surgery due to various non-obstetrical reasons in this study (Table 1).

Because AA was the most common non-obstetrical surgical indication during the pregnancy period, special attention was focussed on the detailed data of this group of patients ( 35 of 52 cases). Table 2 presents the detailed data on the appendectomy cohort. In total, 35 pregnant women with the diagnosis of AA underwent surgery. The mean operation times in the open and laparoscopic approaches were $46.34 \pm 19.01$ and $57 \pm 18.7$ minutes, respectively. The mean hospital stay times in laparoscopic and open approaches were $3.4 \pm 1.7$ and $4.5 \pm 1.6$ days, respectively. Five of the laparoscopic appendectomy (LA) procedures had the requirement to be converted to be open due to various reasons such as an inability to visualise the appendix, severe adhesions, bleeding and technical insufficiency. Histopathologically proven perforated appendicitis was detected in six (17\%) cases. Negative appendectomy was observed in three (9\%) cases. Moreover, postoperative complications were observed in five (14\%) cases as a wound infection, which was

Table 1. Non-obstetrical causes of surgery in pregnancy

\begin{tabular}{|l|l|l|}
\hline Diagnosis & n & $\%$ \\
\hline Acute appendicitis & 35 & 67 \\
\hline Acute biliary pancreatitis & 9 & 17 \\
\hline Acute cholecystitis & 2 & 4 \\
\hline Rupture of ovarian cyst & 2 & 4 \\
\hline Fallopian tube torsion & 1 & 2 \\
\hline Intestinal obstruction & 1 & 2 \\
\hline Splenic aneurysm rupture & 1 & 2 \\
\hline Primary appendicitis epiploicae & 1 & 2 \\
\hline Total & 52 & 100 \\
\hline n: number of patients; \%: percentage & & \\
\hline
\end{tabular}


treated with antibiotics and drainage. There was no foetal or maternal mortality, and also no need for intensive care unit follow-up.

In total, 63 patients with the diagnosis of ABP were treated in our surgical wards. Among them, nine pregnant patients underwent surgery because of intractability to medical treatment and readmission due to recurrent attacks. The Ranson scale was used at admission to assess the severity of ABP. Of all the patients, eight pregnant had the Ranson scores of 1 and 2 and one patient had a Ranson score of 3 (Table 3). Ultrasonography was the first diagnostic tool in all the patients. In one patient with a Ranson score of 3, computerised tomography was used to determine the severity of the disease because of the contraindication of magnetic

Table 2. Demographics, clinical laboratory and pathologic findings of patients with acute appendicitis

\begin{tabular}{|c|c|c|c|}
\hline Parameters & n (35) & $\%$ & Mean \pm SD \\
\hline Age (years) & - & - & $27.4 \pm 6.1$ \\
\hline \multicolumn{4}{|l|}{ Symptoms } \\
\hline Abdominal pain & 35 & 100 & 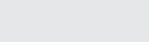 \\
\hline Anorexia & 28 & 80 & \\
\hline Nausea-vomiting & 19 & 54 & - \\
\hline \multicolumn{4}{|l|}{ Physical examination } \\
\hline RLQP & 12 & 34 & - \\
\hline RLQP+rebound & 17 & 49 & - \\
\hline RLQP+defense+rebound & 6 & 17 & - \\
\hline Mean Alvarado score & - & - & $7.6(6-9)$ \\
\hline \multicolumn{4}{|l|}{ Operative technique } \\
\hline Laparoscopic & 8 & 23 & - \\
\hline Conversion to open & 5 & 14 & - \\
\hline Open & 22 & 63 & - \\
\hline \multicolumn{4}{|l|}{ Pathologic results } \\
\hline Normal & 3 & 9 & - \\
\hline Appendicitis & 26 & 74 & - \\
\hline Perforated appendicitis & 6 & 17 & - \\
\hline \multicolumn{4}{|l|}{ Gestation at diagnosis } \\
\hline $1^{\text {st }}$ trimester & 10 & 28 & - \\
\hline $2^{\text {nd }}$ trimester & 17 & 49 & - \\
\hline $3^{\text {rd }}$ trimester & 8 & 23 & - \\
\hline \multicolumn{4}{|l|}{ Mean hospital stay (days) } \\
\hline Laparoscopic & - & - & $3.4 \pm 1.7$ \\
\hline Open & - & - & $4.5 \pm 1.6$ \\
\hline WBC count $\left(\times 10^{3} / \mu \mathrm{L}\right)$ & - & - & $15.1 \pm 6.3$ \\
\hline \multicolumn{4}{|l|}{ Mean operation times (minutes) } \\
\hline Laparoscopic & - & - & $57 \pm 18.7$ \\
\hline Open & - & - & $46.34 \pm 19.01$ \\
\hline Appendiceal Perforation & 6 & 17 & - \\
\hline Postoperative complication (SSI) & 5 & 14 & - \\
\hline Required ICU & - & - & - \\
\hline Preterm foetal morbidity & - & - & - \\
\hline
\end{tabular}

resonance imaging (MRI). MRI is preferably used in the complicated cases of pregnancy. Of all the pregnant women, seven (78\%) underwent laparoscopic cholecystectomy (two cases in the first trimester, one case in the third and four cases in the second trimester) and two (22\%) cases at third trimester were started laparoscopically but were converted to open procedure. The reasons for conversion were adhesions and severe inflammation. Choledocholithiasis was detected in in two patients with high levels of cholestasis enzymes and hyperbilirubinemia via magnetic resonance cholangiopancreatography; moreover, endoscopic retrograde cholangiopancreatography (ERCP) with sphincterotomy was performed in two pregnant women (Table 3). After ERCP, they underwent LC. The conservative management, namely, administration of analgesia, usage of spasmolytics and fluid replacement was started in all the pregnant women. No serious complications such as sepsis, cholangitis, infected necrosis or preterm labour were detected in any of the cases. Patients who

Table 3. Clinical features, treatment strategies and follow-up results of pregnant women with acute pancreatitis

\begin{tabular}{|l|l|}
\hline Parameters & Patients n (\%) \\
\hline Gestational age at diagnosis & $2(22)$ \\
\hline $\mathbf{1}^{\text {st }}$ trimester & \\
\hline $\mathbf{2}^{\text {nd }}$ trimester & $4(44)$ \\
\hline $\mathbf{3}^{\text {rd }}$ trimester & $3(34)$ \\
\hline Readmission & $5(56)$ \\
\hline Ranson scale & \\
\hline $\mathbf{1}$ & $2(22)$ \\
\hline $\mathbf{2}$ & $6(67)$ \\
\hline $\mathbf{3}$ & $1(11)$ \\
\hline $\mathbf{4}$ & - \\
\hline $\mathbf{5}$ & - \\
\hline Revised Atlanta classification & \\
\hline Mild & $8(89)$ \\
\hline Moderate & $1(11)$ \\
\hline Severe & - \\
\hline Radiological Imaging & \\
\hline US & - \\
\hline CT & $9(100 \%)$ \\
\hline Balthazar grade C & - \\
\hline MRCP & - \\
\hline Interventions during pregnancy & $1(11 \%)$ \\
\hline Cholecystectomy & $2(22 \%)$ \\
\hline Laparoscopic & \\
\hline Open & - \\
\hline ERCP + Sphincteretomy & $2(78)$ \\
\hline Mean hospitalisation time & $2(22)$ \\
\hline Laparoscopic & \\
\hline Open & \\
\hline ICU follow-up & \\
\hline ERCP: endoscopic retrograde cholangiopancreatography, ICU: intensive care unit, \\
\hline cholangiopancreatography & \\
\hline
\end{tabular}


underwent cholecystectomy were healed without any complications, and none of pregnant women were admitted to the intensive care unit. There were no foetal and maternal mortality or morbidity during the follow-up periods. Table 3 summarises the demographics, gestational ages, and clinical and diagnostic parameters.

The other causes of non-obstetrical surgery in pregnant women were $A C(n=2)$, rupture of ovarian cyst $(n=2)$, intestinal obstruction $(n=1)$, isolated torsion of fallopian tube $(n=1)$, splenic artery aneurysm (SAA) rupture $(n=1)$ and primary appendicitis epiploicae $(n=1)$ (Table 4). Two pregnant women with the diagnosis of AC were hospitalised and managed conservatively with bed rest, oral stoppage, administration of analgesia, fluid resuscitation and antibiotics. These patients were in the first and second trimesters, respectively. LC was decided for the treatment because of these patients' unresponsiveness to conservative treatment. These two pregnant women had no postoperative complications, and they delivered at term. Laparotomy and cystectomy were performed in two pregnant patients with ovarian cyst rupture in their first and third trimesters, respectively.

Table 4 provide a detailed description of demographic, operative, diagnostic and follow-up results of other causes.

\section{Discussion}

The term acute abdomen in pregnancy refers to any severe acute intra-abdominal condition that is accompanied by pain, tenderness and muscular rigidity. Emergency surgery should be contemplated for this condition, which may result from various obstetric and nonobstetric aetiologies. It is reported that the overall incidence of acute abdomen in pregnant women could be 1/500-635 pregnancies (3). Any gastrointestinal disorder can occur during pregnancy. The literature reports that approximately $0.5-2 \%$ of pregnant women develop an acute abdomen and thus need surgery due to non-obstetric reasons (4). Our study, unlike the literature, found a lower incidence. The number of cases requiring surgical intervention due to non-obstetric reasons in 45,654 pregnant women was $52(0.12 \%)$.

Hizam et al. (5) published a clinical series of 91 cases requiring surgery because of non-obstetric acute abdomen. They reported the following aetiologies: AA (70.4\%), AC (11\%), necrotizing pancreatitis (2.2\%), intestinal obstruction (2.2\%) and peduncular torsion (6.6\%) of ovarian cyst. Andersson et al. (6) also reported the following causes requiring surgery because of non-obstetric acute abdomen: AA, AC, ABP and intestinal obstruction. Our study had following non-obstetric acute abdominal pathologies requiring surgical intervention: $\mathrm{AA}(\mathrm{n}=35,67 \%)$, $\operatorname{ABP}(n=9,17 \%), A C(n=2,4 \%)$, ovarian cyst rupture $(n=2,4 \%)$, fallopian tube torsion $(n=1,2 \%)$, adhesive ileus $(n=1,2 \%)$, spleen aneurysm rupture $(n=1,2 \%)$ and primary appendicitis epiploicae $(n=1,2 \%)$.

The currently reported incidence of AA in pregnant women is $0.04 \%$ (7). AA remains one of the most common non-obstetric surgical emergencies during pregnancy (confirmed in $\sim 1$ in 1.000-2.000 pregnancies). In their series of 20 cases, Kapan et al. (8) reported that the highest incidence of AA was found in the second trimester. They reported a mean Alvarado score of 7.7 (7-9), and $50 \%$ of pregnant women were operated laparoscopically. In our study, AA (n=35) was the most common non-obstetric acute abdominal pathology that required surgical intervention. Moreover, $49 \%$ of appendicitis cases were in the second trimester, with $28 \%$ and $23 \%$ in the first and third trimesters, respectively. The mean Alvarado score of the appendicitis cases was 7.6 (range:6-9). In total, 13 (37\%) patients were operated laparoscopically. In five patients, conversion from laparoscopy to open surgery was required because of insufficient exploration, severe adhesions, bleeding and technical insufficiency. The most common symptom was abdominal pain, and the most common finding was tenderness in the lower right quadrant. Histopathological results were simple appendicitis in 26 (74\%) cases, perforated appendicitis in $6(17 \%)$ cases and normal appendix in $3(9 \%)$ cases. Postoperative complications were detected as wound infections in five cases with appendiceal perforation. Consistent with the literature, most of the pregnant women were in the third trimester. In AA, the foetal mortality rate was $5 \%$, whereas in the case of perforation, this rate increases up to $20 \%$ and also increases the maternal mortality (7). Term delivery occurred in all the pregnant women in our study. There was no maternal or foetal mortality. Wallace et al. (9) reported an overall negative appendectomy rate of $37 \%$ for pregnant patients with presumed AA. In our study, negative appendectomy was observed in three (9\%) cases.

Acute pancreatitis in pregnancy is a very rare condition with a reported rate of 1/10,000 pregnancies and most often occurs in the third trimester (10). In our study, the gestational ages of patients at diagnosis were first

\section{Table 4. The clinical features, operative approaches and follow-up results of the other cases}

\begin{tabular}{|l|l|l|l|l|}
\hline Age (years) & Gestation (weeks) & Diagnosis & Operative techniques & Dutcomes \\
\hline 21 & 15 & Acute cholecystitis & Laparoscopic cholecystectomy & Preterm delivery \\
\hline 27 & 28 & Intestinal obstruction & $\begin{array}{l}\text { Laparotomy-bridotomy } \\
\text { Spontaneous splenic artery }\end{array}$ & $\begin{array}{l}\text { Emergency laparotomy-hemostasis+splenic artery } \\
\text { aneurysm and foetal }\end{array}$ \\
\hline 26 & 33 & Rupture of ovarian cyst & Laparotomy + cystectomy & Preterm delivery \\
\hline 24 & 35 & Isolated fallopian tube torsion & Laparotomy+salpingectomy & Preterm delivery \\
\hline 23 & 34 & Rupture of ovarian cyst & Laparotomy + cystectomy & Abortion \\
\hline 27 & 9 & Acute cholecystitis & Laparoscopic cholecystectomy & Delivery at term \\
\hline 25 & 10 & Primary appendicitis epiploicae & Laparoscopic excision & Delivery at term \\
\hline
\end{tabular}


trimester in two (22\%), second trimester in four (44\%) and third trimester in three patients (34\%). Most often, it is a self-limiting disease but can progress to a more severe condition associated with multi-organ failure, shock and death. The maternal mortality rate is less than $1 \%$, and the rate of preterm delivery is about $20 \%$ (10). In our series, maternal or foetal mortality was not observed; however, pregnancy was ended with preterm labour in two cases who underwent open cholecystectomy. The present guidelines recommend LC during the same admission in the non-pregnant patients with gallstone-induced mild to moderate ABP (11). However, the timing of $L C$ in pregnant patients with ABP remains controversial. The currently accepted indications for surgery in ABP are obstructive jaundice, severe symptoms, signs of peritonitis and AC resistant to conservative management (12). Laparoscopic surgery has been accepted as a safe method for both mother and foetus in the second trimester (12). However, with increasing experiences in laparoscopic surgery, it has been shown that LC can be performed safely at all periods of pregnancy (13). Notably, the recurrence rate of $A B P$ in pregnancy is significantly higher in our study. The patients were readmitted due to the recurrence of pancreatitis at a rate of $56 \%$. This incidence reduces the quality of life of patients and increases the hospital costs. In this case, especially considering this situation, the cholecystectomy procedure can be recommended at any stage of the pregnancy. Additionally, it is crucial to highlight that preferably a laparoscopy should have been performed rather than surgery.

The optimum management of AC in pregnant women is still controversial. Traditionally, LC is usually deferred in uncomplicated cases. However, Swisher et al. (14) reported that a conservative approach is associated with higher recurrence rates in the range of $40-70 \%$. In their decision analysis study, Jelin et al. (15) reported that there was a higher risk of foetal death (7\%) among those patients who underwent conservative management than in those who underwent LC (2.2\%). They concluded that $\mathrm{LC}$ was superior to nonoperative management during the first and second trimesters in pregnant women with gallstone disease. In our series, two pregnant patients with the diagnosis of AC underwent LC. They were at the $10^{\text {th }}$ and $15^{\text {th }}$ weeks of gestation, and there were no postoperative complications. Their pregnancy was ended with term delivery. We think that LC can be a safe and feasible procedure, especially in the first and second trimesters of gestation, for the treatment of AC.

Adhesive ileus in pregnancy is an extremely rare and potentially severe non-obstetric surgical entity that can be associated with a foetal loss of $17 \%$ and maternal mortality of $2 \%$ (16). According to literature, adhesive ileus occurs more commonly in the later periods of pregnancy. The occurrence rates of adhesive ileus have been reported to be $6 \%, 28 \%$, $45 \%$ and $21 \%$ during the first, second, third trimesters and puerperium, respectively (17). In our series, a 27-year-old pregnant patient with a history of previous caesarean section at her third trimester was diagnosed with adhesive intestinal obstruction. At the $48^{\text {th }}$ hour of her follow-up, because of the failure of conservative therapy as denoted by the symptoms of foetal distress, urgent surgical intervention with laparotomy and bridotomy through a midline incision were performed. She had no postoperative complications but underwent preterm delivery at the $36^{\text {th }}$ week of gestation.
The overall risk of rupture increases with the size of the SAA, especially when it is above $2 \mathrm{~cm}$. The initial presentation of SAA has been associated with acute rupture and hemodynamic instability that lead to substantial perioperative morbidity and mortality. Weakness in the arterial walls and an increase in the blood pressure may result in the development of aneurysms (18). These two conditions are known to be augmented in pregnant women. The SAA rupture usually occurs in the third trimester (19). According to the current literature, the mortality following rupture dramatically increases by up to $75 \%$ in pregnant women and is associated with a foetal mortality of $95 \%(20)$. In our series, a 26 -yearold pregnant patient at the gestational age of 33 weeks was admitted in the emergency department for the conditions of hypovolemic shock and intra-abdominal haemorrhage detected in ultrasonography. An emergent laparotomy through the midline incision was performed by a general surgeon and gynaecologists. In this case, 3 litres of blood and hematoma were drained from the abdomen, splenic artery and vein were ligated with splenectomy and distal pancreatectomy to excise the aneurysm that was inseparable from the pancreatic tail. Damage control surgery was performed, and the patient was taken to the intensive care unit for hemodynamic support. But unfortunately, the patient died from multiorgan failure on the second day of the surgery. We can say that if pregnant women with abdominal pain who are at the third trimester have decreased haematocrit levels and intra-abdominal free fluid (detected by the ultrasound), then they should alert the gynaecologists and general surgeons for the possibility of intra-abdominal bleeding. The importance of close follow-up and early surgery should not be forgotten in these patients.

Primary appendicitis epiploicae is a rare clinical entity that probably results from infarction secondary to the torsion of the colonic appendage or the thrombosis of central veins of the appendage. This condition mimics the surgical acute abdomen (21). Diagnostic laparoscopy was employed in a pregnant woman with 18 weeks of gestation due to the consistent pain in lower right quadrant. Laparoscopy demonstrated appendicitis epiploicae in the ascending colon, and laparoscopic simple excision was performed in this patient. She had delivery at term.

Gurbuz and Peetz (22) reported the safety of laparoscopic technique for acute non-obstetric abdominal pathologies during pregnancy, without an additional risk to the foetus. Although it was earlier suggested that laparoscopic surgeries should be performed preferably during the second trimester, recent evidence suggests that laparoscopic surgery can be conducted during any trimester as they have very low rates of maternal and foetal morbidity $(23,24)$. According to SAGES guidelines (25), initial access can be safely accomplished with an open or Hasson's technique in pregnant women. We had used Hasson's open technique in all the cases for an initial access. We adjusted other port locations according to the gestational age and localisation of the pathology and put it under a direct vision. The preferred insufflation pressure was kept at $8-12 \mathrm{mmHg}$ because it reduces the possibility of uterine hypoperfusion and maternal pulmonary events. In our series, laparoscopic surgery had been used in 18 cases with the indications of $A A(n=8)$, acute pancreatitis $(n=7), A C$ $(n=2)$, and primary appendagitis epiploicae $(n=1)$ for both diagnostic and therapeutic purposes. There were no postoperative complications in any of the cases regarding both mother and foetus. The mean hospital 
staying times were 2.8 and 3.44 days for patients who underwent $\mathrm{LC}$ and patient who underwent LA. Seven cases were converted to open surgery; for example, two LA and five LC procedures due to various reasons such as adhesions, severe inflammation, bleeding, the invisibility of appendix and technical insufficiency. All patients who underwent laparoscopic treatment had term labour. Therefore, according to our results, we recommend LA and LC during pregnancy if there is a need for surgery.

This study has several limitations. Because it was a retrospective study, we could not check the accuracy of the diagnosis and the maintained records. In addition, surgical techniques were entirely up to the choice of surgeons. Following the literature, laparoscopy during pregnancy is a safe and effective method in non-obstetric acute abdominal conditions requiring surgical intervention in pregnant women $(26,27)$. The causes of non-obstetric acute abdomen during pregnancy are of great importance due to maternal and foetal mortality.

\section{Conclusion}

Acute abdomen during pregnancy can be caused by obstetric and non-obstetric diseases. These situations can sometimes result in lifethreatening situations for both the mother and foetus. Laparoscopy is applicable and safe in the selected patients for the diagnosis and treatment of acute abdominal pathologies during pregnancy. Understanding anatomical and physiological changes in pregnancy, gaining sufficient information about the safe limits of radiological imaging, and a multidisciplinary systematic approach are indispensable for the timely diagnosis and treatment of pregnant women presenting with an acute abdomen.

\section{Ethics}

Ethics Committee Approval: The study was approved by the ethics committee of University of Health Sciences Turkey, Kanuni Sultan Süleyman Training and Research Hospital (KAEK/2020.05.28).

Informed Consent: All participants and their legal representatives provided written informed consent and assent.

Peer-review: Externally peer-reviewed.

Author Contributions: Concept - Y.K., E.S.; Design - Y.K.; Supervision: E.S., Y.K.; Resources - Y.K., E.S.; Data Collection and/or Processing - Y.K., E.S.; Statistical Analysis - Y.K., E.S.; Analysis and/or Interpretation - Y.K.; Manuscript Preparation - Y.K.; Literature Search - Y.K., E.S.; Writing Manuscript - Y.K., E.S.; Critical Review - E.S.

Conflict of Interest: The authors declare that there is no conflict of interest regarding the publication of this article.

Financial Disclosure: The authors declared that this study received no financial support.

\section{References}

1. Turğal M, Yazıcıoğlu A, Beksaç K, Aran O, Abbasoğlu O, Kaynaroğlu V, et al. Surgical management of non-obstetric acute abdomen during pregnancy: A retrospective review of 24 cases after 8 years' experience. Gynecol Obstet Rebrod Med 2012; 18: 134-7.

2. Hodjati H, Kazerooni T. Location of the appendix in the gravid patient: A reevaluation of the established concept. Int J Gynaecol Obste. 2003; 81: 245-7.
3. Stedman's Medical Dictionary [Accessed July 7, 2018];Stedman's Medical Dictionary, 27th Edition Deluxe. [online] Alibris. 20182 Available from: https://www.ali-bris.com/Stedmans-Medical-Dictionary-27th-EditionDeluxe-Stedmans/book/30000738

4. Malangoni MA. Gastrointestinal surgery and pregnancy. Gastroenterol Clin North Am 2003; 32: 181-200

5. Hizam AR, Hamad CSO, AL-Obaidi MM. Acute abdomen during pregnancy in Baghdad Teaching Hospital (2008-2009) Al-kindy Col Med J 2012; 8: 1-5.

6. Andersson RE, Lambe M. Incidence of appendicitis during pregnancy. Int J Epidemiol 2001;30:1281-5.

7. Angelini DJ. Obstetric triage revisited: update on non-obstetric surgical conditions in pregnancy. J Midwifery Women's Health 2003; 48: 111-8.

8. Kapan S, Bozkurt MA, Turhan AN, Gönenç M, Alıs H. Management of Acute Appendicitis in Pregnancy. Ulus Travma Acil Cerrahi Derg 2013; 19: 20-4.

9. Wallace CA, Petrov MS, Soybel DI, Ferzoco SJ, Ashley SW, Tavakkolizadeh A. Influence of imaging on the negative appendectomy rate in pregnancy. J Gastrointest Surg 2008; 12: 46-50.

10. Pitchumoni CS, Yegneswaran B. Acute pancreatitis in pregnancy. World J Gastroenterol 2009; 15: 5641-6.

11. Murphy PB, Paskar D, Parry NG, Racz J, Vogt KN, Symonette C, et al. Implementation of an Acute Care Surgery Service Facilitates Modern Clinical Practice Guidelines for Gallstone Pancreatitis. J Am Coll Surg 2015; 221: 97581.

12. Talebi-Bakhshayesh M, Mohammadzadeh A, Zargar A. Timing of cholecystectomy after acute severe pancreatitis in pregnancy. Malays J Med Sci 2015; 22: 68-70.

13. Laustsen JF, Bjerring OS, Johannessen Ø, Qvist N. Laparoscopic appendectomy during pregnancy is safe for both the mother and the fetus. Dan Med J 2016; 63: A5259.

14. Swisher SG, Schmit PJ, Hunt KK, Hiyama DT, Bennion RS, Swisher EM, et al. Biliary disease during pregnancy. Am J Surg 1994; 168: 576-81.

15. Jelin EB, Smink DS, Vernon AH, Brooks DC. Management of biliary tract disease during pregnancy: a decision analysis. Surg Endosc 2008; 22: 54-60.

16. Webster PJ, Bailey MA, Wilson J, Burke DA. Small bowel obstruction in pregnancy is a complex surgical problem with a high risk of fetal loss. Ann $R$ Coll Surg Engl 2015; 97: 339-44.

17. Augustin G, Majerovic M. Non-obstetrical acute abdomen during pregnancy. Eur J Obstet Gynecol Reprod Biol 2007; 13: 4-12.

18. Trimble WK, Hill JH. Congestive splenomegaly (Banti's disease) due to portal stenosis without hepatic cirrhosis; aneurysms of the splenic artery. Arch Pathol Lab Med 1942; 34: 423-30.

19. Sadat U, Dar O, Walsh S, Varty K. Splenic artery aneurysms in pregnancy - a systematic review. Int J Surg 2008; 6: 261-5.

20. Caillouette JC, Merchant EB. Ruptured splenic artery aneurysm in pregnancy. Twelfth reported case with maternal and fetal survival. Am J Obstet Gynecol 1993; 168: 1810-3.

21. Kara Y, Cezik A, Uzunlulu N, Șahbaz NA, Çalıșkan YK, Kalaycı MU. Primary Epiploic Appendigitis: A Rare Cause of Acute Abdominal Pain. IKSST Derg 2016; 8: 121-4.

22. Gurbuz AT, Peetz ME. The acute abdomen in the pregnant patient. Is there a role for laparoscopy? Surg Endosc 1997; 11: 98-102.

23. Rollins MD, Chan KJ, Price RR. Laparoscopy for appendicitis and cholelithiasis during pregnancy: a new standard of care. Surg Endosc 2004; 18: 237-41. 
24. Upadhyay A, Stanten S, Kazantsev G, Horoupian R, Stanten A. Laparoscopic management of a nonobstetric emergency in the third trimester of pregnancy. Surg Endosc 2007; 21: 1344-8.

25. Pearl J, Price R, Richardson W, Fanelli R, Society of American Gastrointestinal Endoscopic Surgeons. Guidelines for diagnosis, treatment, and use of laparoscopy for surgical problems during pregnancy. Surg Endosc 2011; 25: 3479-92.
26. Förster S, Reimer T, Rimbach S, Louwen F, Volk T, Bürkle H, et al. CAMIC Recommendations for Surgical Laparoscopy in Non-Obstetric Indications during Pregnancy. Zentralblatt fur Chirurgie 2015; 141: 538-44.

27. Kwon H, Lee M, Park HS, Yoon SH, Lee CH, Roh JW, et al. "Laparoscopic management is feasible for nonobstetric surgical disease in all trimesters of pregnancy." Surgical endoscopy 2018; 32: 2643-9. 